\title{
Exploration and Mapping Utilization of Bitter Melon (Momordica Charantia L.) and Its Culinary
}

\author{
Ummi Rohajatien $^{1 *}$ Wiwik Wahyuni ${ }^{2}$ Aly Imron $^{3}$ \\ ${ }^{1,2}$ Department of Industrial Technology, UniversitasNegeri Malang, Jl. Semarang No.5 \\ ${ }^{3}$ State Polytechnic of Malang, Jl Sukarno-Hatta no. 9 Malang \\ *Corresponding author :Ummi.rohajatien.ft@um.ac.id ; ummir99@gmail.com
}

\begin{abstract}
Bitter melon and its culinary in Indonesia was known as vegetable and traditionally is also used as phlegm decay, febrifuge and appetite. The aim of the research was to identify bitter melon utilization as well as culinary processing as case study of great Malang area. The research was conducted using survey method and observation with questionnaire and observation guidance. The research finding showed the utilization of bitter melon to the respondent especially was as complementary staple food ingredient and family medicinal plants (toga). Responders also stated that bitter melon was consumed as complement of the main course, snack food and dessert. Utilization of bitter melon as family medicine was consumed in form of juice or juice as herb. Most of the responders believed that by consuming juice of bitter melon could reduce blood sugar levels (diabetic), cholesterol, hypertension, skin itching, digestion, bloated and cancer for women. Journal published by health ministry of Republic of Indonesia 2015 stated that bitter melon was common utilized as vegetable or treatment. The result of the questionnaire also exposed that the goal of community planting this bitter melon was to consume as vegetable plants as well as used as specific goal of a treatment.
\end{abstract}

Keywords: bitter melon, culinary, its utilization

\section{INTRODUCTION}

Pare plant (Momordicacharantia L), is a kind of vines with long jagged fruit and pointed edges. This vegetable plant is a member of the pumpkin tribe or cucurbitacea which has been cultivated as a vegetable or medicinal plant. The name momordica which is attached to the binomial naming of this plant in Latin means "bite" which shows the leaf edge of the plant in the genus Momordica which is jagged like a bite mark (Rukmana, 1999). This plant is a tropical plant that is classified as a seasonal plant that lives creeping and creeping. This plant is widely planted in the fields of fields, fields or former rice paddies as interrupts during the dry season. Pare has a high adaptability to grow, can adapt to different climates both temperature and high rainfall, can still be green and does not depend on the season. Bitter melon plants require adequate soil drainage, loose soil and a lot of organic matter. Pare plants can grow at an altitude between $1 \mathrm{~m}$ to 1500 meters above sea level (Santoso, 1996).

Pare plants are classified as cucurbitaceae, the type of Momordicacharantia L spread includes China, India and Southeast Asia (Williams, 1971). Utilization of bitter melon fruit for the people of southern Japan as a laxative, laxative and worm medicine (Okabe et al., 1980), in India Pare fruit extract is used as a diabetic drug, rheumatic medicine, liver disease medication and drug for lymphoma (Dixit et al. , 1978). Bitter melon fruit in Indonesia, besides being known as a vegetable, is also traditionally used as a sputum, a medicine to reduce heat and increase appetite. Bitter melon leaves are used as menstrual decay, medicine for burns, drugs for skin diseases and medicine for worms (Pramono et al., 1988).

\section{RESEARCH METHODS}

Exploration of the use of bitter melon fruit and its culinary which was carried out in this first phase of research covered 4 villages in Malang City and Regency. In Malang, the research was carried out in Kedung corral and Madyopuro villages in KedungKandang sub-district, while in Malang regency was conducted in Pakis village and in Slatri sub-district in Kasembon sub-district.

\section{RESULTS AND DISCUSSION}

The results of this study indicate that: 1) all respondents stated that they knew bitter melon and most of the respondents stated that bitter melon grew in their area, 2) a small portion of respondents stated that they plant bitter melon in their yards / yard, on the fence or in the fields. The results of the questionnaire also revealed that the 
to as white bitter melon and green bitter melon. Sastroamidjojo, S. (1965) mentions that there are three kinds of bitter melon which are known, namely frog pare whose fruit is short, chicken pare whose fruit is also short, and pare pedestal or pare leuweung. This kind of bitter melon also divides it into bitter pariah, green pariah and snake pariah which have physical characteristics. The fruit is elliptical and tapered at the tip, has irregular piles, a bitter taste, green fruit which will turn dark yellow if it is cooked, mushy and broken. Recapitulation of the results of exploration of the use of bitter melon fruit and culinary are presented in Table 1.

Table 1. Exploration of the Utilization of Bitter Melon and Culinary

\begin{tabular}{|c|c|c|c|c|c|c|c|c|c|c|}
\hline \multirow[t]{3}{*}{ No. } & \multirow[t]{3}{*}{ Parameter } & \multicolumn{9}{|c|}{ Number of respondents (people) } \\
\hline & & \multicolumn{2}{|c|}{$\begin{array}{l}\text {.Madyopuro } \\
\text { Village }\end{array}$} & \multicolumn{2}{|c|}{$\begin{array}{c}\text { Kedung } \\
\text { Kandang } \\
\text { Village }\end{array}$} & \multicolumn{2}{|c|}{ Pakis Village } & \multicolumn{2}{|c|}{ Slatri Village } & \multirow{2}{*}{$\begin{array}{l}\text { Average } \\
\%\end{array}$} \\
\hline & & $\begin{array}{l}\text { frequ } \\
\text { ency }\end{array}$ & $\%$ & $\begin{array}{l}\text { freq } \\
\text { uen } \\
\text { cy }\end{array}$ & $\%$ & $\begin{array}{l}\text { frequ } \\
\text { ency }\end{array}$ & $\%$ & $\begin{array}{l}\text { frequ } \\
\text { ency }\end{array}$ & $\%$ & \\
\hline 1. & $\begin{array}{l}\text { Getting to know bitter } \\
\text { melon }\end{array}$ & 20 & 100 & 20 & 100 & 20 & 100 & 20 & 100 & 100 \\
\hline 2. & $\begin{array}{l}\text { Planting bitter melon } \\
\text { on: } \\
\text { 1. yard / } \\
\text { home page } \\
\text { 2. fence } \\
\text { 3. gardens / fields }\end{array}$ & $\begin{array}{l}7 \\
4\end{array}$ & $\begin{array}{l}45 \\
35 \\
20\end{array}$ & $\begin{array}{l}10 \\
4 \\
6\end{array}$ & $\begin{array}{l}50 \\
20 \\
30\end{array}$ & $\begin{array}{l}13 \\
1 \\
6\end{array}$ & $\begin{array}{c}65 \\
5 \\
30\end{array}$ & $\begin{array}{l}11 \\
0 \\
9\end{array}$ & $\begin{array}{l}55 \\
0 \\
45\end{array}$ & $\begin{array}{l}53.75 \\
15 \\
31.25\end{array}$ \\
\hline 3. & $\begin{array}{l}\text { Plant parts that are } \\
\text { used: } \\
1 \text { piece } \\
\text { 2. leaves } \\
\text { 3. seeds }\end{array}$ & $\begin{array}{c}16 \\
3 \\
1\end{array}$ & $\begin{array}{c}80 \\
15 \\
5\end{array}$ & $\begin{array}{c}15 \\
3 \\
2\end{array}$ & $\begin{array}{l}75 \\
15 \\
10\end{array}$ & $\begin{array}{c}17 \\
2 \\
1\end{array}$ & $\begin{array}{c}85 \\
10 \\
5\end{array}$ & $\begin{array}{c}18 \\
1 \\
1\end{array}$ & $\begin{array}{l}90 \\
5 \\
5\end{array}$ & $\begin{array}{l}82.5 \\
11.25 \\
6.25\end{array}$ \\
\hline 4. & $\begin{array}{l}\text { utilizations of bitter } \\
\text { melon: } \\
\text { 1. food ingredients } \\
\text { 1.1. Complementary } \\
\text { food main menu with } \\
\text { processing methods: } \\
\text { a. boiled } \\
\text { b. steamed } \\
\text { c. saute / saute } \\
\text { 1.2. food / snack: } \\
\text { a. dumplings } \\
\text { b. pecel } \\
\text { c. fresh vegetables } \\
\text { 1.3. dessert: pudding }\end{array}$ & $\begin{array}{c}6 \\
2 \\
12 \\
\\
13\end{array}$ & $\begin{array}{l}30 \\
10 \\
60 \\
5\end{array}$ & $\begin{array}{c}0 \\
0 \\
20\end{array}$ & $\begin{array}{c}0 \\
0 \\
100 \\
100\end{array}$ & $\begin{array}{c}4 \\
4 \\
12\end{array}$ & $\begin{array}{l}20 \\
20 \\
60 \\
50\end{array}$ & $\begin{array}{c}6 \\
4 \\
10\end{array}$ & $\begin{array}{l}30 \\
20 \\
50 \\
55\end{array}$ & $\begin{array}{l}20 \\
12.5 \\
67.5 \\
\\
67.5\end{array}$ \\
\hline
\end{tabular}




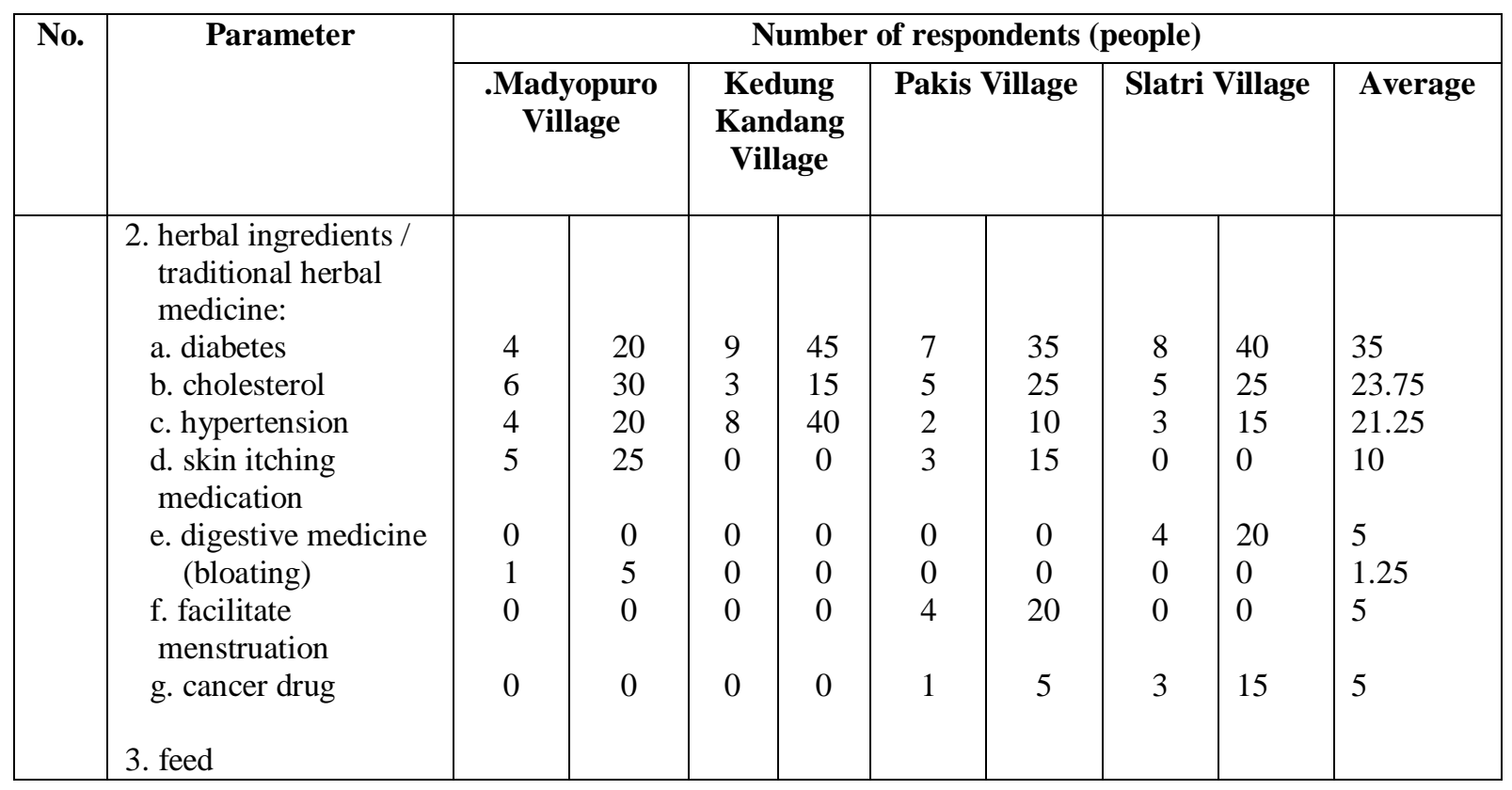

The use of bitter melon by respondents mainly is as food and as a family medicinal plant (toga). Utilization for food is consumed as a complement to the main menu (main course), as a sepinggan food (snacks) and as a dessert (dessert). The use of bitter melon as a family medicine is consumed in the form of juice or fruit juice as an herbal medicine. Respondents stated: using 21 bitter melon for traditional medicinal purposes / herbal medicine (herbal medicine) as many as 21 people $(26.25 \%)$, using bitter melon for lowering high blood pressure as many as 16 people (20\%), taking advantage of bitter melon for diabetes / urinary drugs sweet as many as 22 people (27.5\%), using bitter melon for cholesterol drugs as many as 5 people $(6.25 \%)$, using bitter melon for itching on the skin as much as 6 people (7.5\%), using bitter melon for digestion / bloating 5 people $(6.25 \%)$, used 1 bitter melon to facilitate menstruation by 1 person $(1.25 \%)$, and used 1 bitter melon for cancer drugs (1.25\%). Most respondents believe that by consuming bitter melon juice or bitter melon juice can reduce blood sugar levels (diabetes), cholesterol, hypertension, skin itching, bloating digestion and cancer in women. Journal published by the Ministry of Health of the Republic of Indonesia in 2015, revealed that bitter melon fruit is usually used as a vegetable or medicine. The efficacy of bitter melon for treatment as released by the Ministry of Health of the Republic of Indonesia is 1) to help treat diabetes. Bitter melon fruit does not contain compounds so that if consumed long term it can compensate for chemical drugs which of course will cause side effects if consumed continuously. 2) bitter melon fruit can help the process of weight loss, 3) relieve breathing, 4) suppress the growth of cancer cells, 5) beautify the skin, 6) and suppress the development of the HIV virus. All respondents stated: utilizing bitter melon as a complement to the main menu in the form of processed stir-fried bitter melon, steamed bitter melon used as vegetables and boiled bitter melon served with peanut sauce, known as pecel seasoning. A total of 21 respondents (26.25\%) stated: using bitter melon as a snack / snack in the form of dumplings. Respondents who claimed to use bitter melon as a dessert (dessert) in the form of pudding pare as much as 1 person (1.25\%). The use of bitter melon as a culinary addition to the types of culinary that has been described previously is in the form of: fried sambal / godog sambal for 4 respondents (5\%), krengsengan as many as 3 respondents $(3.75 \%)$, spicy stirfry for 1 respondent $(1.25 \%)$, curry vegetables 3 respondents $(3.75 \%)$ and vegetable respondents 1 respondent $(1.25 \%)$. The use of bitter melon as a complement to the main menu and as a snack / snack has been done for a long time by the people of Indonesia. Indonesian people have long consumed bitter melon as food. Pariah curry cuisine has long been processed and consumed by the Minangkabau community, pariah kumbu has long been processed and consumed by the people of Sumbawa.Stir fry/Oseng-oseng pare or stir-fried bitter melon is also a culinary that is processed and consumed by many people in Purwokerto. While papare is a menu of processed bitter melon fruit which is widely processed and consumed by the people of Manado (Anonymous, 2007).

Some respondents consumed bitter melon as a dessert food as a bitter gourd pudding. The recipes and photos of bitter melon can be seen in Appendix 16. Processed bitter melon as a dessert (dessert) is not yet widely known and consumed by the people of Indonesia. Types of dessert bitter melon or bitter melon cakes that have been known and consumed by Indonesian people do not use bitter melon as their raw material, but use sticky rice flour as the main ingredient. Pare cake or bitter cake is known and widely consumed by the people of Palembang (Anonymous, 2007). 
hypoglycaemic effects of Momordica charantia (bitter melon): a mini review. British Journal of Nutrition 2009, 102:17031708.

[12] Anonymous, 2007: Momordica Charantia (Bitter Melon) Altern. Med. Rev. Monograph. 12:360- 363

[13] Morton, JF. 2008. The balsam pear - an edible, medicinal and toxic plant. Econ. Bot. 21:57- 68.

[14] Okabe H, Miyahara Y, Yamauchi T, Miyahara K, Kawasaki T. 1980. Studies on the Constituents of Momordica charantia $L$. Isolation and Characterization of Momordicoside $A$ and B, Glycosides of $a$ Pentahydroxy Cucurbitane Triterpen.. Chem. Pharm. Bull 28: 2753.

[15] Platel,K., Sharpalekar,K.S., and Srinivasan,K., 1993. Inference of bitterguard (Momordica charantia Linn) on growth and blood constituents in albino rats, Nahrung 37, 156-160

[16] Pramono S, Ngatijan, Sudarsono S. Budiono, Pujoarianto A. 1988. Obat Tradisional Indonesia I. Pusat Penelitian Obat Tradisional UGM. Yogyakarta, h. 18.

[17] Rukmana, R. 1999. Budidaya Pare. Kanisius. Yogyakarta

[18] Santoso,W. 1996. Usaha Tani Tanaman Pare. Jakarta: Instalasi Penelitian dan Pengkajian teknologi Pertanian DKI Jakarta.

[19] Snee, L.S., V.R. Nerurkar, D.A. Dooley, J.T. Efird, A.C. Shovic and P.V. Nerurkar. 2011. Strategies to improve palatability and increase consumption intentions for Momordica charantia (bitter melon): A vegetable commonly used for diabetes management.) Nutrition Journal

[20] T. Miura, T. Kawata, S. Takagi, M. Nanpei, H. Nakao, E. Ishihara, I. Ishida. Effect of Momordica charantia on adenosine monophosphate-activated protein kinase in genetically type 2 dibetic mice muscle. Journal of Health Science. 2009; 55(5):805.

[21] WHO. 2006. Reseach guidelines for evaluating the savety and efficacy of herbal medicines. Manila: WHO Regional Officer for Western Pacific. p. 35

[22] Williams JF, Ng NO. 1971. Variation within Momordica charantia L. The Bitter Gourd (cucurbitaceae). Ann. Bogoriensis, 6: 11.

[11] Leung L, Birwhistle R, Kotecha L, Hannah S, Cuthbertson S, Anti-diabetic and 